\title{
Identification of Citrullus lanatus Germplasm Accessions Tolerant to Clomazone Herbicide
}

\author{
Howard F. Harrison, Jr. ${ }^{1}$, Chandrasekar S. Kousik, and Amnon Levi \\ U.S. Department of Agriculture, Agricultural Research Service, U.S. Vegetable \\ Laboratory, 2700 Savannah Highway, Charleston, SC 29414
}

Additional index words. watermelon, citronmelon, pickling melon, Citrullus lanatus var. citroides and var. lanatus, clomazone

\begin{abstract}
Clomazone herbicide is registered for use in watermelon; however, crop tolerance is marginal, and the recommended use rates $(0.17$ to $0.28 \mathrm{~kg}$ a.i./ha) are lower for watermelon than for other crops. In a greenhouse germplasm evaluation experiment including 56 germplasm accessions and watermelon cultivars, three Citrullus lanatus var. citroides PI accessions (PI 482324, PI 5003540, and PI 532624) were not injured by clomazone, whereas most of the other accessions and cultivars were moderately or severely injured. A greenhouse concentration response experiment demonstrated that the clomazone concentration required to cause moderate injury to the tolerant 'PI 500354' was approximately three times the concentration required to cause similar injury to the susceptible citroides accession 'PI 244017', and the concentration required to cause 50\% shoot biomass reduction was approximately five times greater for 'PI 500354' than for 'Charleston Gray' watermelon. Subsequent field experiments demonstrated that two tolerant accessions ('PI 500354' and 'PI 482324') were injured less initially by clomazone and recovered more rapidly from clomazone injury than two susceptible accessions ('PI 244017 ' and 'PI 271773') and two watermelon cultivars ('Charleston Gray' and 'Crimson Sweet'). Tolerant germplasm accessions like 'PI 482324' and 'PI 500354' may be useful as sources of clomazone tolerance in watermelon breeding. Chemical name used: clomazone 2 [(2-chlorophenyl)methyl]-4,4-dimethyl-3-isoxazolidinone\}.
\end{abstract}

Watermelon is grown on over 60,000 ha in the United States and is an important crop in many states. The herbicide clomazone (Anonymous, 2005) is widely used in watermelon production in the United States, except California. It controls many important annual weeds, and the number of weed species controlled increases with the rate of application. The recommended use rates for watermelon are 0.17 for coarse soils and $0.28 \mathrm{~kg} \cdot \mathrm{ha}^{-1}$ for fine soils. Clomazone application rates are higher for other crops, for instance recommended rates for soybeans [Glycine max L. (Merr.)] grown in southern states on coarse soils are between 1.1 and $1.4 \mathrm{~kg} \cdot \mathrm{ha}^{-1}$. Even at low rates, clomazone can cause moderate injury to young watermelon plants that is expressed as chlorosis of leaves and growing tips.

We first observed differential clomazone tolerance among Citrullus germplasm accessions when the herbicide was used for weed control in research plots at the U.S. Vegetable Laboratory. Hines and Wilson (1992) reported that watermelon cultivars varied in clomazone injury in a greenhouse experiment; however, the cultivars included in their experiment were not listed. Cultivars of other cucurbit crops have also been shown to vary in tolerance.

Received for publication 22 Sept. 2010. Accepted for publication 1 Mar. 2011.

We thank Lance Lawrence for technical assistance. ${ }^{1}$ To whom reprint requests should be addressed; e-mail howard.harrison@ars.usda.gov.
Staub et al. (1991) screened the U.S. germplasm collection of cucumber (Cucumis sativus L.) for clomazone tolerance in the field and identified tolerant and susceptible accessions based on injury ratings. In a greenhouse evaluation of selected accessions, the differences in tolerance were not as great as in the field screening experiment. Al-Khatib et al. (1995) demonstrated differences in clomazone tolerance among five cucumber cultivars in greenhouse and field experiments. The greatest differences in tolerance were observed with injury ratings taken at 4 weeks after planting in the field and with leaf area and plant dry weights in the greenhouse. After observation of differences in clomazone injury in a field cultivar trial, Harrison and Keinath (2003) evaluated 67 pumpkin [Cucurbita maxima Duchesne, C. moschata Duchesne (Poir.), C. pepo L.] cultivars for tolerance in the greenhouse. Differences in tolerance were greatest between the species marketed as pumpkins; however, differences in tolerance were also observed among cultivars within species. Watermelon was most susceptible to clomazone among six cucurbit crops (Figueroa and Kogan, 2005) based on early-season injury ratings and growth measurements. However, clomazone at up to $0.9 \mathrm{~kg} \cdot \mathrm{ha}^{-1}$ did not affect crop yields. Boyhan et al. (1995) reported that watermelon yields were reduced by clomazone applied pre-emergence at 1.1 and $1.7 \mathrm{~kg} \cdot \mathrm{ha}^{-1}$ to direct seeded watermelon. Grey et al. (2000) reported that clomazone at $0.84 \mathrm{~kg} \cdot \mathrm{ha}^{-1}$ applied preplant-incorporated, preplant to the soil sur- face, and post-transplant to the soil surface caused minor foliar bleaching (14\% injury or less) but did not reduce the yields of seeded or transplanted 'Royal Sweet' watermelon. Cohen et al. (2008) concluded from a greenhouse study that clomazone at 1.0 and $2.0 \mathrm{~kg} \cdot \mathrm{ha}^{-1}$ was too injurious to grafted and non-grafted watermelons to be used safely. Variation among cultivars in clomazone tolerance has been reported in several non-cucurbit crops, including bean (Phaseolus vulgaris L.) (Sikkema et al., 2006), cabbage (Brassica oleracea L.) (Hopen et al., 1992), corn (Zea mays L.) (Keifer, 1989), and rice (Oryza sativa L.) (Mudge et al., 2005; Scherder et al., 2004; Zhang et al., 2004).

The first objective of this study was to evaluate clomazone tolerance in a diverse germplasm collection of watermelon cultivars and germplasm accessions of Citrullus lanatus and closely related species. Subsequent greenhouse and field experiments were conducted to assess the differences in tolerance of selected accessions identified in the germplasm evaluation experiment.

\section{Materials and Methods}

Greenhouse experiments. The greenhouse used in these experiments was located at the U.S. Vegetable Laboratory, Charleston, SC. Temperatures ranged between 20 and $32{ }^{\circ} \mathrm{C}$, supplemental lighting was not provided, and humidity was increased from ambient by an evaporative cooling system. The greenhouse potting medium was a $1 / 1(\mathrm{v} / \mathrm{v})$ blend of a commercial potting mixture (Metro-Mix 360; Sun Gro Horticultural Distribution Inc, Bellevue, WA) and washed river sand. Powdered limestone and controlled-release fertilizer (Osmocote 15-9-12 plus; The Scotts Co. LLC, Marysville, $\mathrm{OH}$ ) at $1.1 \mathrm{~g} \cdot \mathrm{L}^{-1}$ were added, and the mixture was blended in a portable cement mixer for $5 \mathrm{~min}$. Clomazone was incorporated into the potting medium by adding the appropriate volume of the commercial formulation (Command $3 \mathrm{ME}$; FMC Corp., Philadelphia, PA) to $500 \mathrm{~mL}$ of water, spraying the dilution directly onto the potting mixture in a concrete mixer using a handheld sprayer followed by mixing for $10 \mathrm{~min}$. A clomazone concentration of $1.5 \mathrm{mg} \cdot \mathrm{kg}^{-1}$ dry potting mix was selected for germplasm evaluation based on the results of a preliminary experiment that indicated this concentration causes moderate to severe injury to watermelon cultivars. The clomazone-treated potting mixture was used to fill $475-\mathrm{mL}$ polystyrene foam cups. Seeds were planted in cups containing clomazone-treated soil and placed in the greenhouse. Cups were watered as necessary to maintain moist potting mixture. After 3 weeks, plants were rated for clomazone injury on a 1 to 10 scale in which $1=$ no chlorosis, $4=\approx 30$ to $40 \%$ of shoot tissue chlorotic, $7=\approx 60$ to $70 \%$ of tissue chlorotic, and $10=$ plants completely chlorotic or dead.

The germplasm evaluation experiment included 56 lines that exhibited good seed germination and variable clomazone tolerance in a preliminary screening experiment. Most of the accessions were obtained from the USDA, 
ARS, Plant Genetic Resources Conservation Unit, Griffin, GA, and are designated as PIs. This experiment was arranged in a randomized complete block design with four replications. The data were analyzed using the PROCPAR1WAY procedure of SAS (SAS System, 2008) and ranked using Wilcoxon rank scores.

Seeds of PI accessions with high clomazone tolerance or susceptibility were produced from greenhouse-grown, self-pollinated plants for use for subsequent experiments. A greenhouse experiment was conducted to quantify the relative tolerance of three Citrullus lines to clomazone. The lines included the tolerant C. lanatus var. citroides accession 'PI 500354', the susceptible citroides accession 'PI 244017', and the watermelon cultivar Charleston Gray. The two PI accessions were selected over others with similar injury ratings in the germplasm evaluation experiment, because seeds were available. Clomazone concentrations were $0,0.75,1.5,3.0,6.0$, and $12.0 \mathrm{mg} \cdot \mathrm{kg}^{-1}$ potting medium. The experiment was arranged in a randomized complete block design with four replications and was repeated. Planting dates were 28 May and 26 June 2008. At 3 weeks after planting, plants were rated for clomazone injury as described previously and shoot dry weights were measured. Data from the two replicates of the experiment were combined and subjected to analysis of variance. No treatment-by-experiment interaction was observed; therefore, the data from both experiments were combined for further analysis. Nonlinear regression analyses (proc nlin; SAS System, 2008) using the nonparallel dose-response curves procedure described by Seefeldt et al. (1995) were used to estimate the concentration of clomazone required to cause a midscale injury rating of 5.5 $\left(\mathrm{I}_{5.5}\right)$ and $50 \%$ shoot dry weight reduction $\left(\mathrm{GR}_{50}\right)$ with the three genotypes.

Field experiment. A field experiment was conducted once in 2009 and twice in 2010 to confirm the differences in clomazone tolerance observed in the greenhouse. The soil type at the U.S. Vegetable Laboratory research farm is a Yonges fine silty sand (Typic Endoaqualfs). The soil $\mathrm{pH}$ was $6.4,6.6$, and 6.5 and soil organic matter was below $0.5 \%$ for the 2009 and the first and second 2010 experiments, respectively. Watermelons were grown using standard cultural practices. Fertilizer $(10 \mathrm{~N}-$ $4.4 \mathrm{P}-8.3 \mathrm{~K}$ ) was broadcast on the plot area at $1100 \mathrm{~kg} \cdot \mathrm{ha}^{-1}$ before field preparation. Land used for the experiment was shaped into beds (15 cm high and $0.8 \mathrm{~m}$ wide) spaced $4 \mathrm{~m}$ apart. Approximately 4-week-old greenhouse-grown seedlings were manually transplanted on the beds at $1-\mathrm{m}$ spacing. Transplanting dates were 26 Aug. 2009, 21 Apr. 2010, and 13 May 2010. The experiment was arranged in a split plot design with five replications. Main plot treatments included clomazone at 0 (an untreated control) and $0.63 \mathrm{~kg} \cdot \mathrm{ha}^{-1}$. Subplot treatments consisted of the Citrullus lanatus var. citroides accessions 'PI 244017', 'PI 271773', 'PI 482324', and 'PI 500354' and the watermelon cultivars Charleston Gray and Crimson Sweet. Subplots consisted of five plants in the 2009 experiment and 10 plants in the 2010 experiments. Clomazone was broadcast over the treated plots in $102 \mathrm{~L} \cdot \mathrm{ha}^{-1}$ with a $\mathrm{CO}_{2}$ pressurized plot sprayer $24 \mathrm{~h}$ or more before transplanting and watered in with $\approx 2.5-\mathrm{cm}$ sprinkler irrigation. Individual plants were rated for clomazone injury weekly for 4 weeks for the 2009 experiment and 5 weeks for the 2010 experiments using a scale of 0 to 10 in which $0=$ no chlorosis, $3=\approx 30 \%$ of foliage chlorotic, $7=\approx 70 \%$ of foliage chlorotic and plants stunted, and $10=$ plants completely chlorotic or dead. The field ratings collected over time for each genotype were analyzed as repeated-measures data using the nonparametric analysis described by Arkitas and Brunner (1997) and Brunner et al. (2002). The analysis was performed using SAS macros F1_LD_F1 and LD_CI to determine the effect of clomazone on genotypes over time. The macro files can be downloaded for free from the web site (<http://www.ams.med.uni-goettingen. de/de/sof/ld/makros.html $>$ ). Pairwise comparison of the effect of clomazone on the genotypes over time was done at $P=0.05$ using the output generated by the mentioned SAS macros.

\section{Results and Discussion}

Greenhouse experiments. Injury ratings of 36 of the accessions in the germplasm evalu-

Table 1. Injury ratings for watermelon and related species germplasm accessions (PI) and cultivars grown in a greenhouse potting medium containing clomazone herbicide at $1.5 \mathrm{mg} \cdot \mathrm{kg}^{-1}$.

\begin{tabular}{|c|c|c|c|c|c|c|c|c|c|}
\hline Genotype & $\begin{array}{l}\text { Citrullus } \\
\text { species }^{z}\end{array}$ & $\begin{array}{l}\text { Injury } \\
\text { rating }^{y}\end{array}$ & SEM & $\begin{array}{l}\text { Mean } \\
\operatorname{rank}^{x}\end{array}$ & Genotype & $\begin{array}{c}\text { Citrullus } \\
\text { species }\end{array}$ & $\begin{array}{l}\text { Injury } \\
\text { rating }\end{array}$ & SEM & $\begin{array}{c}\text { Mean } \\
\text { rank }\end{array}$ \\
\hline PI 482324 & $\mathrm{CLC}$ & 1.0 & 0.00 & 17 & Raspa & CLL & 4.5 & 0.87 & $\overline{134}$ \\
\hline PI 500354 & CLC & 1.0 & 0.00 & 17 & PI 217938 & $\mathrm{PF}$ & 4.5 & 0.65 & 136 \\
\hline PI 532624 & CLC & 1.0 & 0.00 & 17 & PI 244019 & CLC & 4.5 & 0.96 & 132 \\
\hline PI 485583 & CLC & 1.3 & 0.25 & 24 & PI 296341 & CLC & 4.5 & 1.04 & 135 \\
\hline PI 482319 & CLC & 1.5 & 0.29 & 31 & Festival & CLL & 4.8 & 0.48 & 146 \\
\hline PI 482379 & CLC & 1.5 & 0.50 & 32 & PI 244018 & CLC & 4.8 & 1.11 & 143 \\
\hline PI 505604 & CLC & 1.5 & 0.50 & 32 & PI 500329 & CLL & 4.8 & 0.85 & 143 \\
\hline PI 482303 & CLL & 1.8 & 0.48 & 39 & PI 540911 & $\mathrm{PF}$ & 4.8 & 0.25 & 146 \\
\hline PI 482338 & CLC & 1.8 & 0.48 & 39 & PI 381741 & CLL & 4.8 & 0.63 & 145 \\
\hline PI 248178 & CLL & 2.0 & 0.41 & 46 & PI 470260 & LS & 4.8 & 1.11 & 136 \\
\hline PI 500331 & CLC & 2.0 & 0.41 & 46 & $\begin{array}{c}\text { Au-Sweet } \\
\text { Scarlet }\end{array}$ & CLL & 5.0 & 0.91 & 151 \\
\hline PI 105445 & CLL & 2.0 & 0.00 & 45 & Big Stripe & CLL & 5.0 & 0.71 & 154 \\
\hline PI 459074 & CLL & 2.3 & 0.75 & 58 & Calhoun Gray & CLL & 5.0 & 0.82 & 152 \\
\hline PI 482259 & CLC & 2.3 & 0.25 & 53 & Grif 5601 & $\mathrm{PF}$ & 5.0 & 0.41 & 155 \\
\hline PI 248774 & CLC & 3.0 & 0.71 & 81 & PI 635722 & C. $\mathrm{sp}$ & 5.0 & 0.41 & 155 \\
\hline Crimson Sweet & CLL & 3.3 & 0.25 & 88 & Verona & CLL & 5.3 & 0.25 & 164 \\
\hline PI 164539 & CLL & 3.3 & 0.25 & 88 & Ole & CLL & 5.5 & 0.29 & 173 \\
\hline $\begin{array}{l}\text { Black } \\
\text { Diamond }\end{array}$ & CLL & 3.5 & 0.50 & 97 & $\begin{array}{r}\text { Stars and } \\
\text { Stripes }\end{array}$ & CLL & 5.5 & 0.29 & 173 \\
\hline Mickey Lee & CLL & 3.5 & 0.29 & 98 & PI 227202 & CLL & 5.5 & 0.50 & 173 \\
\hline PI 427298 & $\mathrm{PF}$ & 3.8 & 0.48 & 107 & PI 193964 & CLL & 5.8 & 1.03 & 172 \\
\hline Patriot & CLL & 4.0 & 0.82 & 118 & PI 381734 & CLL & 5.8 & 1.38 & 161 \\
\hline PI 381749 & $\mathrm{PF}$ & 4.0 & 0.82 & 118 & PI 386015 & $\mathrm{CO}$ & 5.8 & 0.25 & 182 \\
\hline PI 449332 & $\mathrm{PF}$ & 4.0 & 0.41 & 118 & PI 636137 & LS & 5.8 & 1.03 & 172 \\
\hline PI 482266 & CLL & 4.0 & 0.41 & 118 & $\begin{array}{c}\text { Charleston } \\
\text { Gray }\end{array}$ & CLL & 6.5 & 0.29 & 204 \\
\hline PI 526231 & CLL & 4.0 & 0.41 & 118 & PI 244017 & CLC & 6.5 & 0.29 & 205 \\
\hline PI 381755 & $\mathrm{PF}$ & 4.3 & 0.25 & 128 & PI 386016 & $\mathrm{CO}$ & 6.5 & 0.29 & 205 \\
\hline PI 392291 & CLL & 4.3 & 0.25 & 128 & PI 271773 & CLC & 6.8 & 0.25 & 212 \\
\hline Allsweet & CLL & 4.5 & 0.50 & 137 & PI 386019 & $\mathrm{CO}$ & 7.3 & 0.63 & 215 \\
\hline
\end{tabular}

${ }^{\mathrm{z}}$ Citrullus species designations indicate: $\mathrm{CLL}=$ Citrullus lanatus var. lanatus; $\mathrm{CLC}=$ C. l. var. citroides; $\mathrm{CO}=C$. colocynthis; LS = Laegenaria siceraria $; \mathrm{PF}=$ Praecitrullus fistulosus. PI 635722 is listed as Citrullus species in the GRIN database.

${ }^{\mathrm{y}}$ The Kruskal-Wallis $\chi^{2}$ was $166.88, P \leq 0.0001$ indicating significant differences among accessions.

${ }^{\mathrm{x}}$ Mean ranks are based on analysis of the data using proc NPAR1WAY of SAS and indicate the Wilcoxon ranks. 
susceptible accession or cultivar in these greenhouse experiments.

Field experiments. The field experiments confirmed our observation in the greenhouse that 'PI 500354' was more tolerant to clomazone than 'Charleston Gray' and 'PI 244017' (Table 3). Of the accessions in this experiment that were not included in the greenhouse doseresponse experiment, 'PI 482324' had tolerance similar to 'PI 500354', and 'PI 271773' was susceptible similar to 'PI 244017' and 'Charleston Gray'. 'Crimson Sweet' was intermediate between the two highly tolerant citroides accessions and 'Charleston Gray' in tolerance and had lower mean ranks than 'Charleston Gray' in two of three experiments. 'Crimson Sweet' was also intermediate between the most and least tolerant accessions in the preliminary greenhouse screening experiment (Table 1). 'PI 500354' and 'PI 482324' had lower mean ranks than 'PI 244017', 'PI 271773', 'Charleston Gray', and 'Crimson Sweet' in all three field experiments. The clomazone rate used in this study, $0.63 \mathrm{~kg} \cdot \mathrm{ha}^{-1}$, is 3.7 times the recommended rate for watermelons grown on coarse soils, $0.17 \mathrm{~kg} \cdot \mathrm{ha}^{-1}$. We observed that clomazone at the recommended rate did not injure the most tolerant Citrullus accessions; thus, a rate higher than is recommended was used to quantify tolerance. The tolerant accessions recovered from clomazone injury, and average injury ratings at 5 weeks after transplanting were 1.0 for 'PI 500354' and 0.8 for 'PI 482324'. This level of injury consisted of marginal chlorosis on older leaves only. Average injury ratings ranged between
3.3 and 4.0 for the other accessions and cultivars at 5 weeks (data not presented). Significance levels for genotype by time interactions were $P=0.02,0.003$, and 0.059 for the Fall 2009, Spring 2010, and Summer 2010 experiments, respectively, and these also indicate a difference among genotypes in rates of recovery from clomazone injury.

The most tolerant Citrullus lanatus accessions identified in this study belonged to the variety group citroides. Susceptible $C$. lanatus var. citroides accessions were also identified. C. lanatus var. citroides is common as a wild watermelon in southern Africa and has wide genetic diversity (Levi et al., 2001a) compared with watermelon cultivars (Levi et al., 2001b). Some genotypes are cultivated and are called citron melon or pickling melon. Genotype(s) became naturalized in the eastern United States and are a weed of cultivated lands (Bryson and DeFelice, 2009). 'PI 244017' and 'PI 271773' were collected in South Africa, 'PI 482324' was collected in Zimbabwe, and 'PI 500354' was collected in Zambia. Watermelon cultivars varied in clomazone tolerance; however, none included in this study were as tolerant as 'PI 482324' and 'PI 500354'. The relatively high tolerance found in these accessions has encouraged us to study the genetic inheritance of clomazone tolerance and investigate the potential for increasing clomazone tolerance in watermelon using conventional plant breeding approaches. The $C$. lanatus var. citroides PIs are readily crossed with watermelon cultivars (C. lanatus var. lanatus). However, a wide genetic distance exists between

Table 2. Estimated ${ }^{\mathrm{z}}$ clomazone concentrations (mg a.i./kg potting medium) required to cause midscale injury ratings of $5.5\left(\mathrm{I}_{5.5}\right)$ or shoot weight reduction of $50 \%$ of the control dry weight $\left(\mathrm{GR}_{50}\right)$ in a greenhouse experiment.

\begin{tabular}{|c|c|c|c|c|c|c|c|c|}
\hline \multirow[b]{2}{*}{ Genotype } & \multirow{2}{*}{$\begin{array}{c}\mathrm{I}_{5.5} \\
\left(\mathrm{mg} \cdot \mathrm{kg}^{-1}\right)\end{array}$} & \multirow[b]{2}{*}{ SE } & \multicolumn{2}{|c|}{$95 \%$ confidence limits } & \multirow{2}{*}{$\begin{array}{c}\mathrm{GR}_{50} \\
\left(\mathrm{mg} \cdot \mathrm{kg}^{-1}\right)\end{array}$} & \multirow[b]{2}{*}{ SE } & \multicolumn{2}{|c|}{$95 \%$ confidence limits } \\
\hline & & & Lower & Upper & & & Lower & Upper \\
\hline $\begin{array}{l}\text { Charleston } \\
\text { Gray }\end{array}$ & 2.42 & 0.13 & 2.17 & 2.67 & 1.45 & 0.79 & -0.11 & 3.01 \\
\hline PI244017 & 1.67 & 0.09 & 1.49 & 1.85 & 1.91 & 0.46 & 1.00 & 2.82 \\
\hline PI 500354 & 5.04 & 0.22 & 4.61 & 5.48 & 7.33 & 1.29 & 4.79 & 9.87 \\
\hline
\end{tabular}

${ }^{\mathrm{z}} \mathrm{I}_{5.5}$ and $\mathrm{GR}_{50}$ estimates were determined using the log-logistic equation: $\mathrm{y}=C+\frac{D-C}{1+\exp [b(\log (x)-\log (150))]}$ in which $C=$ lower limit; $D=$ upper limit; and $b=$ slope. Estimated coefficients ( \pm approximate SES) for the injury rating equations were $C=9.16 \pm 0.18, D=0.87 \pm 0.14$, and $b=2.89 \pm 0.38,2.61 \pm 0.34$, and $4.31 \pm$ 0.71 for 'Charleston Gray', 'PI 244017', and 'PI 500354', respectively. Estimated coefficients for the shoot growth equations were $C=0.05 \pm 0.21, D=1.71 \pm 0.09$, and $b=0.75 \pm 0.35,2.27 \pm 1.07$, and $3.89 \pm 2.11$ for 'Charleston Gray', 'PI 244017', and 'PI 500354', respectively.

Table 3. Injury ratings (IRs) averaged over rating dates and mean ranks for injury ratings for six Citrullus lanatus genotypes treated with clomazone at $0.63 \mathrm{~kg} \cdot \mathrm{ha}^{-1}$ pre-transplanting and rated weekly for 4 (2009) or 5 (2010) weeks after transplanting in three field experiments conducted in Charleston, SC. ${ }^{z}$

\begin{tabular}{|c|c|c|c|c|c|c|c|c|c|c|}
\hline \multirow[b]{2}{*}{ Genotype } & \multirow{2}{*}{$\begin{array}{c}\text { C. lanatus } \\
\text { variety group }\end{array}$} & \multicolumn{3}{|c|}{ Fall 2009} & \multicolumn{3}{|c|}{ Spring 2010} & \multicolumn{3}{|c|}{ Summer 2010} \\
\hline & & IR & SEM & Mean $\operatorname{rank}^{\mathrm{x}}$ & IR & SEM & Mean rank & IR & SEM & $\overline{\text { Mean rank }}$ \\
\hline $\begin{array}{c}\text { Charleston } \\
\text { Gray }\end{array}$ & 1 & 4.5 & 1.8 & $77 \mathrm{a}$ & 6.5 & 1.2 & $105 \mathrm{a}$ & 4.9 & 1.8 & $58 \mathrm{a}$ \\
\hline $\begin{array}{r}\text { Crimson } \\
\text { Sweet }\end{array}$ & 1 & 3.6 & 1.3 & $57 \mathrm{a}$ & 5.7 & 1.2 & $85 \mathrm{~b}$ & 3.7 & 1.2 & $44 \mathrm{~b}$ \\
\hline PI 244017 & $\mathrm{c}$ & 5.2 & 1.0 & $88 \mathrm{a}$ & 6.2 & 1.6 & $99 \mathrm{ab}$ & 5.4 & 1.6 & $65 \mathrm{a}$ \\
\hline PI 271773 & $\mathrm{c}$ & 5.4 & 1.0 & $91 \mathrm{a}$ & 5.7 & 1.8 & $88 \mathrm{ab}$ & 5.4 & 1.5 & $66 \mathrm{a}$ \\
\hline PI 500354 & $\mathrm{c}$ & 1.0 & 1.0 & $31 \mathrm{~b}$ & 3.6 & 2.0 & $46 \mathrm{c}$ & 2.0 & 1.5 & $22 \mathrm{c}$ \\
\hline PI 482324 & $\mathrm{c}$ & 1.9 & 1.0 & $20 \mathrm{~b}$ & 2.8 & 1.5 & $30 \mathrm{~d}$ & 1.7 & 0.9 & $18 \mathrm{c}$ \\
\hline
\end{tabular}

zTransplanting dates were 26 Aug. 2009, 26 Apr. 2010, and 13 May 2010 for the Fall 2009, Spring 2010, and Summer 2010 experiments, respectively.

${ }^{\mathrm{y}}$ Genotypes designated 1 are watermelon cultivars and genotypes designated $\mathrm{c}$ are PI accessions belonging to the variety group C. lanatus var. citroides.

${ }^{\mathrm{x}}$ Mean ranks within columns followed by the same letter are not different $(P=0.05)$. them (Jarret et al., 1997; Levi et al., 2001a) and a strong preferential segregation for a large number of gene loci exists in F2 populations derived from crosses between $C$. lanatus var. citroides accessions and watermelon cultivars (Levi et al., 2002, 2006). Thus, in addition to crosses with watermelon cultivars, we have constructed genetic populations derived from crosses between clomazone-tolerant and -susceptible $C$. lanatus var. citroides accessions. These genetic populations (F2, BC1 populations) should have normal (Mendelian) segregation for most gene loci and facilitate a straightforward genetic inheritance study. The genetic inheritance study and genetic mapping of the gene loci conferring clomazone tolerance will be useful in our future efforts to incorporate clomazone tolerance into watermelon cultivars.

\section{Literature Cited}

Al-Khatib, K., S. Kadir, and C. Libbey. 1995. Broadleaf weed control with clomazone in pickling cucumber (Cucumis sativus). Weed Technol. 9:166-172.

Anonymous. 2005. Command 3ME herbicide label, EPA Reg. No. 279-3158. FMC Corp., Philadelphia, PA.

Arkitas, M.G. and E. Brunner. 1997. A unified approach to rank tests for mixed models. J. Statist. Plann. Inference 61:249-277.

Boyhan, G.E., S.P. Kovach, J.D. Norton, B.R. Abrahams, H.M. Hollingsworth, and J.M. Dangler. 1995. Preemergence herbicides for cantaloupe and watermelon. J. Veg. Crop Prod. 1: 79-92.

Brunner, E., S. Domhof, and F. Langer. 2002. Nonparametric analysis of longitudinal data in factorial experiments. John Wiley \& Sons, New York, NY.

Bryson, C.E. and M.S. DeFelice. 2009. Weeds of the South. University of Georgia Press, Athens, GA.

Cohen, R., H. Eizenberg, M. Edelstien, C. Horev, T. Lande, A. Porat, G. Achdari, and J. Herschenhorn. 2008. Evaluation of herbicides for selective weed control in grafted watermelon. Phytoparasitica 36:66-73.

Figueroa, R. and M. Kogan. 2005. Clomazone selectivity among six cucurbit crops. Agrociencia 39:611-618

Grey, T.L., D.C. Bridges, and D.S. NeSmith. 2000. Tolerance of cucurbits to the herbicides clomazone, ethanlfluralin, and pendimethalin. II. Watermelon. HortScience 35:639-641.

Harrison H.F., Jr. and A.P. Keinath. 2003. Glasshouse assessment of clomazone response in U.S. pumpkin cultivars. Crop Prot. 22:795798.

Hines, T.E. and H.P. Wilson. 1992. Varietal tolerance to clomazone. Proc. Northeastern Weed Sci. Soc. 46:27 (abstr.).

Hopen, H.J., R.L. Hughes, and B.A. Michaelis. 1992. Selectivity among cabbage cultivars to clomazone. Weed Technol. 7:471-477.

Jarret, R.L., L.C. Merrick, T. Holms, J. Evans, and M.K. Aradhya. 1997. Simple sequence repeats in watermelon [Citrullus lanatus (Thunb.) Matsum. \& Nakai]. Genome 40:433-441.

Keifer, D.W. 1989. Tolerance of corn (Zea mays) lines to clomazone. Weed Sci. 37:622-628.

Levi, A., C.E. Thomas, T. Joobeur, X. Zhang, and A. Davis. 2002. A genetic linkage map for watermelon derived from a testcross population: (Citrullus lanatus var. citroides $\times C$. lanatus 
var. lanatus $) \times C$. colocynthis. Theor. Appl. Genet. 105:555-563.

Levi, A., C.E. Thomas, A.P. Keinath, and T.C. Wehner. 2001a. Genetic diversity among watermelon (Citrullus lanatus and Citrullus colocynthis) accessions. Genet. Resources Crop Evol. 48: 559-566.

Levi, A., C.E. Thomas, T.C. Wehner, and X. Zhang. $2001 \mathrm{~b}$. Low genetic diversity indicates the need to broaden the genetic base of cultivated watermelon. HortScience 36:1096-1101.

Levi, A., C.E. Thomas, T. Trebitsh, A. Salman, J. King, J. Karalius, M. Newman, O.U.K. Reddy, Y. Xu, and X. Zhang. 2006. An ex- tended linkage map for watermelon based on SRAP, AFLP, SSR, ISSR and RAPD markers. J. Amer. Soc. Hort. Sci. 131:393402.

Mudge, C.R., E.P. Webster, C.T. Leon, and W. Zhang. 2005. Rice (Oryza sativa) cultivar tolerance to clomazone in water seeded production. Weed Technol. 19:907-911.

System, S.A.S. 2008. Version 9.2. SAS Institute Inc., Cary, NC.

Scherder, E.F., R.E. Talbert, and S.D. Clark. 2004. Rice (Oryza sativa) cultivar tolerance to clomazone. Weed Technol. 18:140144.
Seefeldt, S.S., J.E. Jensen, and E.P. Fuerst. 1995. Log-logistic analysis of dose response relationships. Weed Technol. 9:218-227.

Sikkema, P.H., C. Shropshire, and N. Soltani. 2006. Effect of clomazone on various market classes of dry beans. Crop Prot. 26:943-947.

Staub, J., L. Crubaugh, H. Baumgartner, and H. Hopen. 1991. Screening of the cucumber germplasm collection for tolerance to clomazone herbicide. Cucurbit Crop Genet. Rep. 14:22-24.

Zhang, W., E.P. Webster, D.C. Blouin, and S.D. Linscombe. 2004. Differential tolerance of rice (Oryza sativa) varieties to clomazone. Weed Technol. 18:73-77. 